\title{
ユーラシア圈におけるアーチ横架材の構法の分類と分布 \\ THE CLASSIFICATION AND DISTRIBUTION OF THE ARCH MEMBER OF CONSTRUCTION SYSTEM IN EURASIA
}

\author{
李強*, 北川啓介**, 夏目欣昇 ${ }^{* * *}$, 若山 滋**** \\ Qiang LI, Keisuke KITAGAWA, Yoshinori NATSUME \\ and Shigeru WAKA YAMA
}

In this research, we aim at clarifying the classification and distribution of the arch member for exploring a relation between the natural climate and propagation of culture style in Eurasia area in future. According to the form, material and the means of constructing, seven attributes of the arch member are defined and each attribute is classified into several different types. By analyzing the interrelation of the attributes and the map of distribution we summarized feature and distribution of the arch member of each type, and furthermore we found that the elevation of the arch member distributed over the area of Gothic style is simple, on the contrary, the elevation of the arch member distributed over the area of Islamic style area is various. In Spain and the northwestern part of France, the east coast area in the Mediterranean, the western part of India and the northeast part of China, coexistence of various type of the arch member is confirmed.

Keywords : the arch member, construction system, Eurasia, classification, distribution アーチ横架材, 構法, ユーラシア圈, 分類, 分布

1.はじめに

建築物を構法という視点から分析するとき, その基本的な要素とし て架構のシステムに着目することが可能である。その場合, 柱（ある いは壁）からの中間的な部材を経て，アーチあるいは水平材といった 横架材にいたる一連の部材の組み合わせは, それだけで一つの建築構

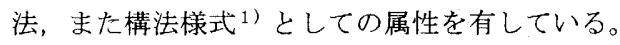

本研究では構法を特に部分的な架構のシステムとして, 建築物の部 分に対応するものという考え方をとる。つまり規模の大きい建築物に は複数の構法が存在することになる。先行論文として, すでに水平横 架材についての分類と分布の研究を行った ${ }^{2)}$ 。本稿では, ア一チ横架 材に着目し，その構法様式の分類と分布から，ア一千横架材の各属性 の性質と地理的特性を把握し, 自然風土あるいは文化様式の伝播 ${ }^{31}$ との関係を探る一助とする。

まず, 歴史的建築 ${ }^{4)}$ に関する網羅的な内容をもつ文献 ${ }^{5)}$ から，アー 于横架材を抽出し, 形態, 力学的作用, 材料といった属性により分類,

集計する。更に, 分類別の構成, 分布を含めたそれらの関係を考察す る。

\section{2. 研究の範囲}

本研究の研究対象地域は，ヨーロッパから東アジアに至る「ユーラ
シア圈」 ${ }^{6)}$ とする。この圈域は, 自然風土的多様性を内包し, また相 互の文化文明の濃密な交流の歴史を有し, 他の地域の歴史とは一線を 画している。

また, 分析対象のア一チ横架材は 19 世紀以前の高度な様式性をもっ

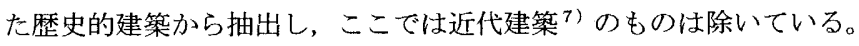

\section{3. アーチ横架材の分類}

\section{$3-1$. 定義と分類}

本研究では, 部分的な架構のシ ステムを構成する主要な要素を 下から垂直材, 中間部（柱頭, 接 合材), 横架材 (水平・アーチ) と定義した。アーチ横架材とは， 架構のシステムに拉いて垂直材 間に曲線状に架け渡した部材を指す

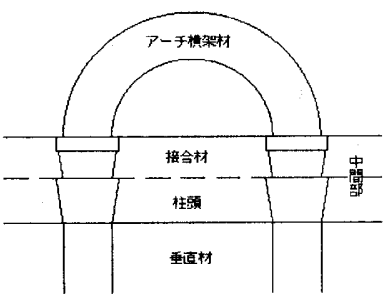

図一1 架構のシステム (図一1)。

抽出文献から 1417 のアーチ横架材を分析対象として抽出した。抽 出基準は，(1)写真が鮮明である(2)柱から横架材までが写っている(3)原 形をとどめている，もしくは保存状態がよい(4)建築された場所と年代 がはっきりしている，の 4 点である。

\footnotetext{
名古屋工業大学大学院工学研究科 博士後期諜程・修士 (工学)

** 名古屋工業大学大学院工学研究科 講師・博士 (工学)

*** 名古屋工業大学大学院工学研究科 助手 $\cdot$ 修士 (工学)

**** 名古屋工業大学大学院工学研究科 教授.工博
}

Graduate Student, Graduate School of Engineering, Nagoya Institute of Technology, M. Eng.

Assistant Prof., Graduate School of Engineering, Nagoya Institute of Technology, Dr. Eng.

Research Assoc., Graduate School of Engineering, Nagoya Institute of Technology, M. Eng.

Prof., Graduate School of Engineering, Nagoya Institute of Technology, Dr. Eng. 

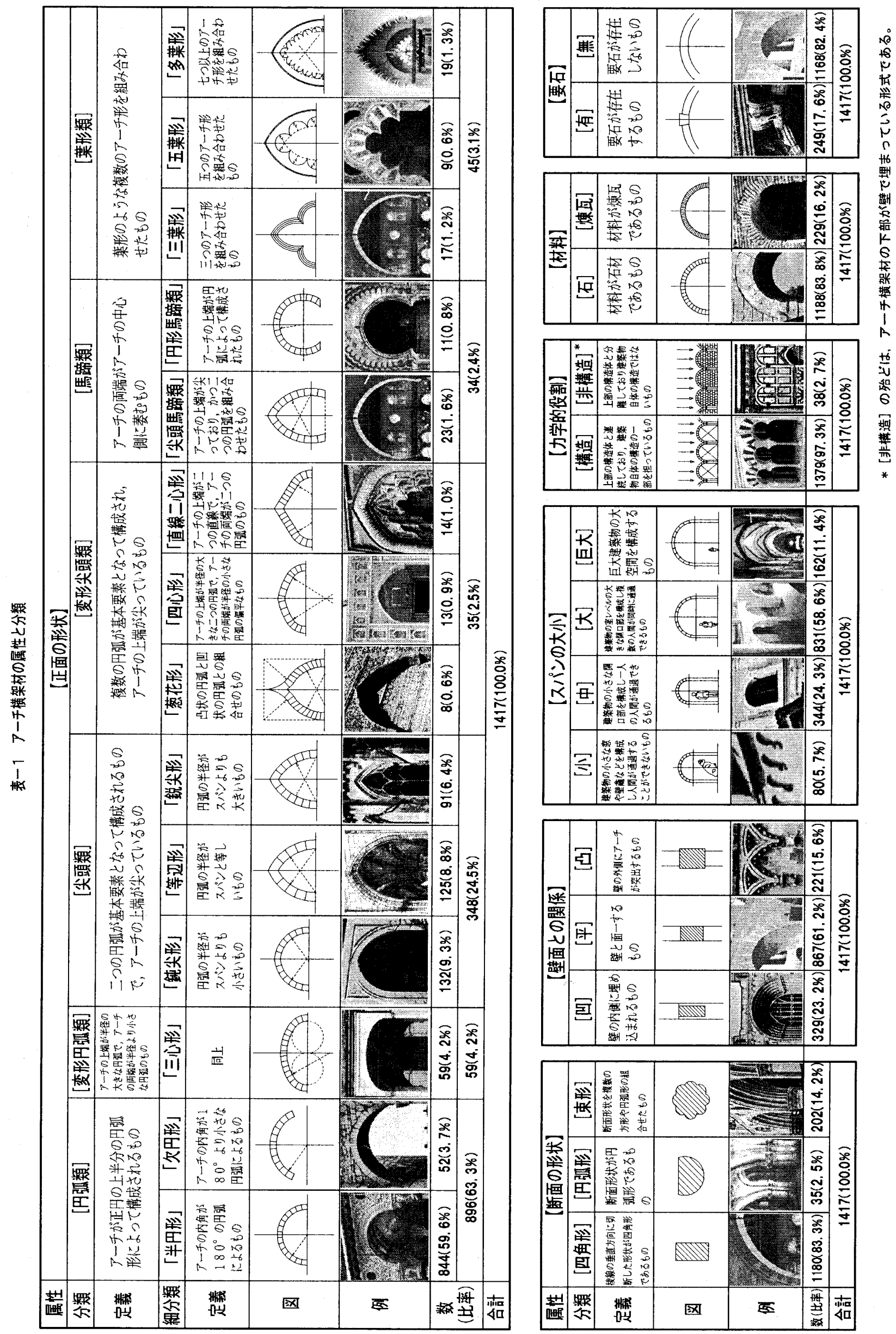
ア一チ横架材構法の形態, 力学, 材料の性質を把握するため, 【正 面の形状】、【断面の形状】、【壁面との関係】、【ス゚ンの大小】、【学 的役割】、材料】、要石】の 7 種類の属性に着目し, 分類 - 考察を行 った（表一1）。【正面の形状】は，形態が多様であり，文化の様相も 反映されていると考えられるので，本稿ではこの【正面の形状】をア 一千横架材の重要な属性とみなし，この分類を中心に考察を進める。

\section{$3-2$, 考察}

【正面の形状】では, 最も単純で基本的な形である [円弧類]が半数 以上を占め,ア一チ横架材の基本形といえる。次に[尖頭類]は約 2 $5 \%$ 占め, 準基本形といえる。[馬蹄類]と [葉形類]はわずかであり, 宗教や文化形式の影響を受け流行した発展形と推測できる。【断面の 形状】では, 最も単純な形状である[四角形]が大半を占める中, 形状 が複雑な [束形]が約 14 ，2％あり，[束形]はア一千横架材を稜線方 向に細く見せる傾向と思われる。[円弧形]はわずかである。【壁面と の関係】について，最も単純な関係である[平]が 6 割を占める。また， 開口部の奥行を強調する[凹]が，アーチの正面の形状を強調する[凸] よりも多く，歴史的建築の奥行感を重視した構図傾向と考えられる。 【スパンの大小】については，[大]のものを中心に，[小]から[巨大] までが確認できた。【力学的役割】では，[構造]が圧倒的に多く[非構 造]は2，7\%であった。【材料】では，殆どが[石]であり，[棟瓦]は 1 6. $2 \%$ であった。アーチ横架材における材料の選択は，施工寸る 上での必然性に関わるため，4章で建築構法を取り巻く他の諸要因と の関係について考察する。【要石】では，[無]が圧倒的に多い。

\section{4.アーチ横架材の【正面の形状】と他属性の相互関係}

【正面の形状】と他属性の分類を比較考察することを通じ, 各類別 の性質を分析する。

（1）【正面の形状】と【断面の形状】

[尖頭類]の【断面の形状】は[四角形]である割合が低いが, 特に「鋭 尖形」と「等辺形」は【断面の形状】の[束形]との関連性が強い。一 方, [変形尖頭類], [馬蹄類], [葉形類]の【断面の形状】は, 基本形 の[四角形]が多い。つまり，[尖頭類]は【断面の形状】に変化をもた せる傾向がある(図一2)。

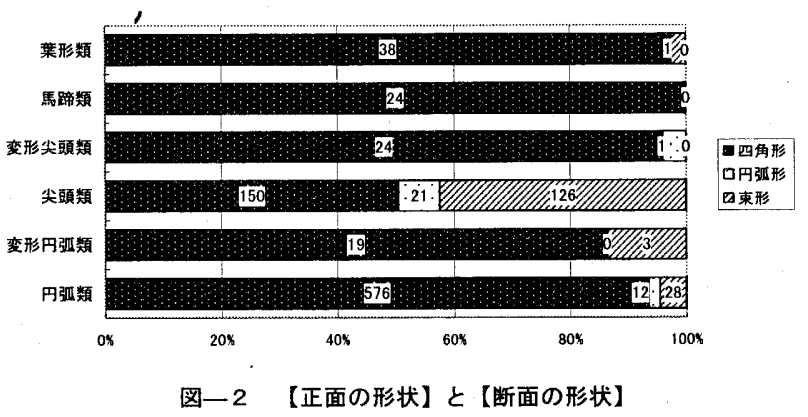

（2）【正面の形状】と【壁面との関係】

[尖頭類]は【壁面との関係】が[凹]である割合が高く、アーチの上 端が尖る程その傾向は強い。一方【正面の形状】の発展形の中でも,

「葱花形」、「円形馬蹄形」、「尖頭馬蹄形」、「多葉形」の【壁面との関 係】は, 基本形である[平]の割合が高い。[尖頭類]は複数のアーチが 重なって多重アーチを形成することも多く，【壁面との関係】とも相 まって，奥行を表現する傾向がある（図ー3）。

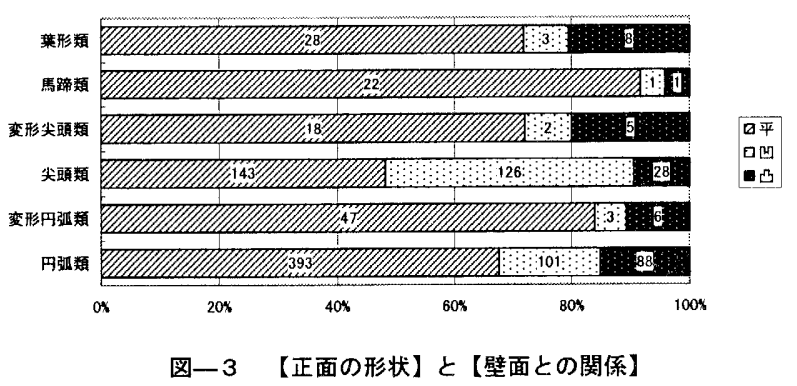

(3)【正面の形状】と【スパンの大小】

[尖頭類]は[巨大]が 2 割を超え,これは大スパンのアーチの基本形 態である。逆に，[葉形類]は[小]が 2 割以上を占め，また，[巨大]が みられないことから，大空間には使用されないことがわかる(図－4）。

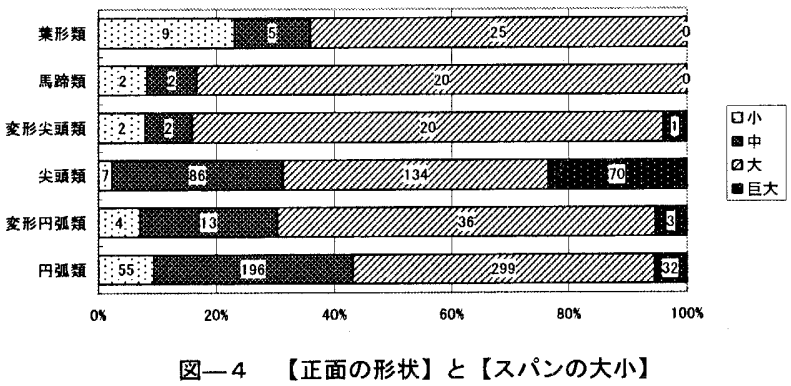

(4)【正面の形状】と【力学的役割】

今回の分析対象の結果から, 殆どのアーチは【力学的役割】が[構 造]であったが,【正面の形状】が[円弧類］，[葉形類]のア一チは，[非 構造了として使われる割合が他の類型に比べて高い（図一 5 ）。

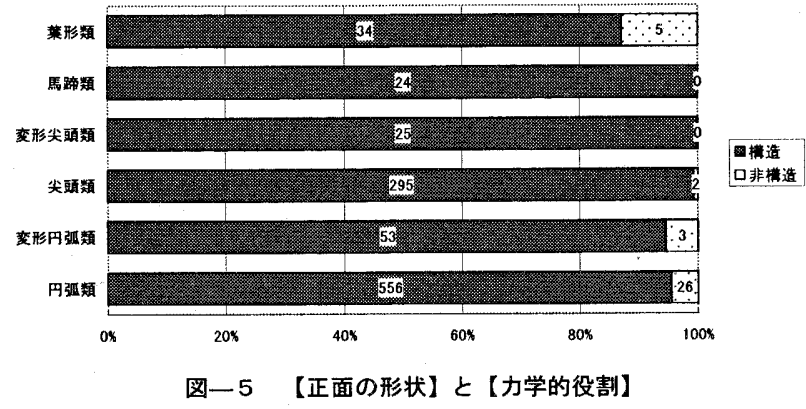

(5)【正面の形状】と【材料】

「鉎尖形」、「半円形」に[煉瓦]が用いられる割合が高く，力の流れ に対して無理が少ない。[石］と[棟瓦]の両方が用いられる無難なア一 于横架材構法であると思われる。[馬蹄類]は力学的に[棟瓦]の使用が 難しい。[葉形類] 微細な部材が多く, 施工性の点で[煉瓦]の応用が 少ない(図-6)。

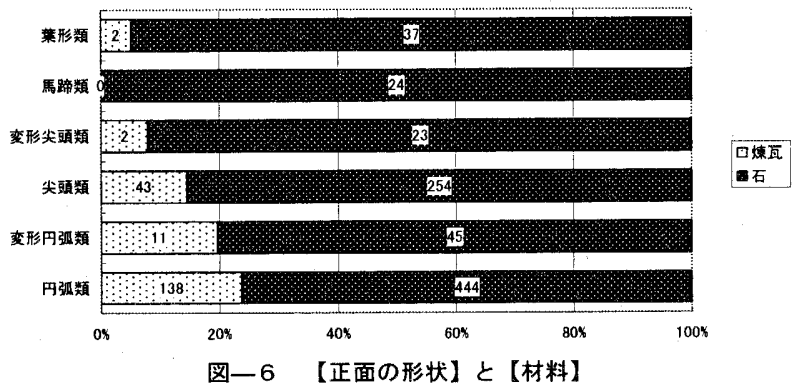

(6)【正面の形状】と【要石】

「三形」に【要石】が[有]の割合が高く、「多葉形」、「直線二心 


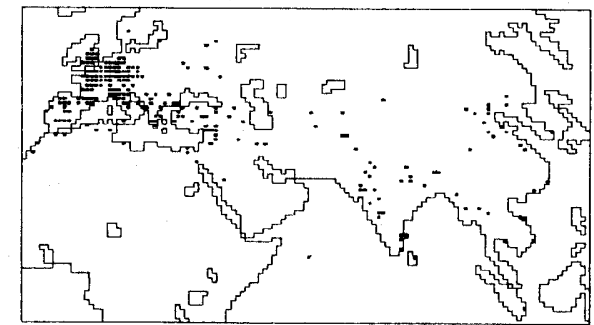

图一8 全体データの分布
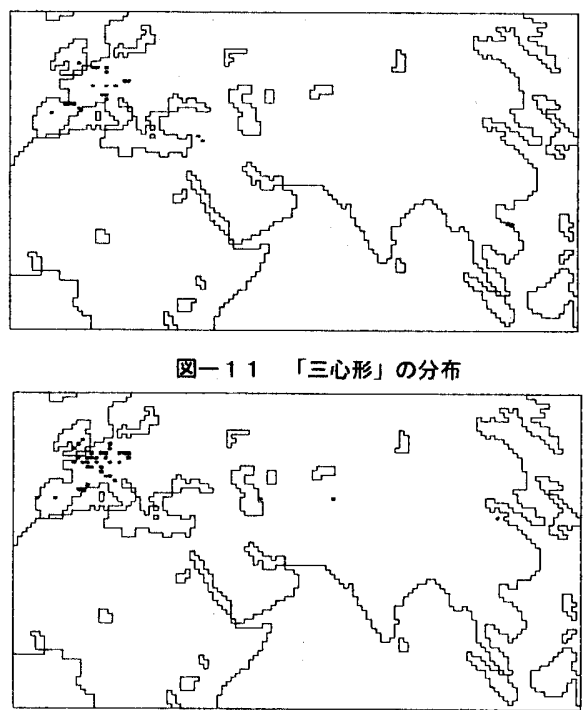

图一 14 「釦尖形」の分布

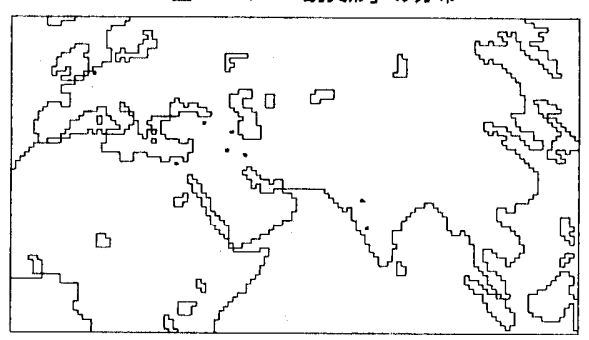

图-17「直線二心形」の分布
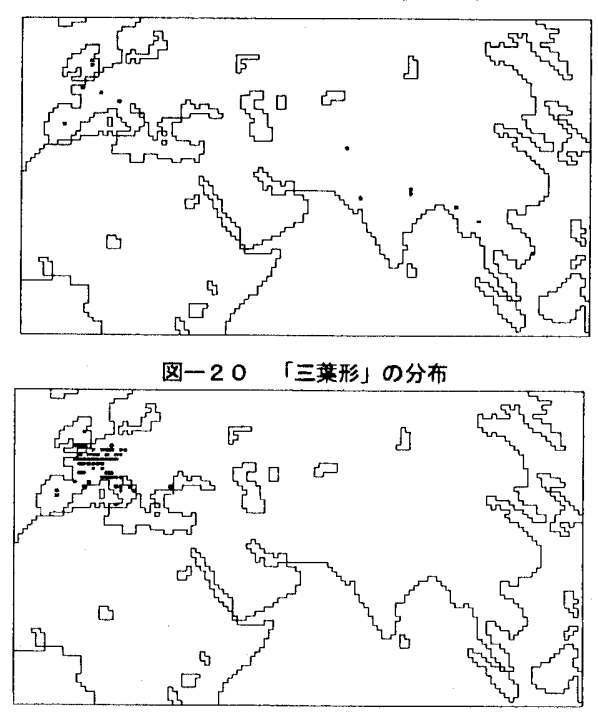

图一23 [巨大] の分布

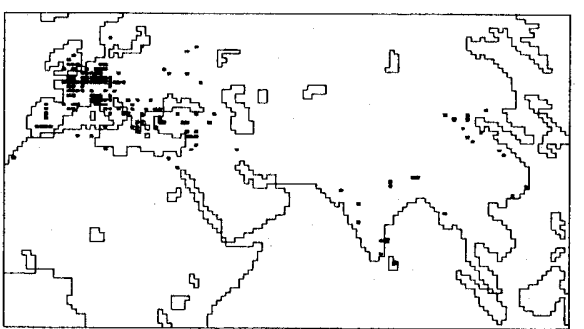

图一个「半円形」の分布

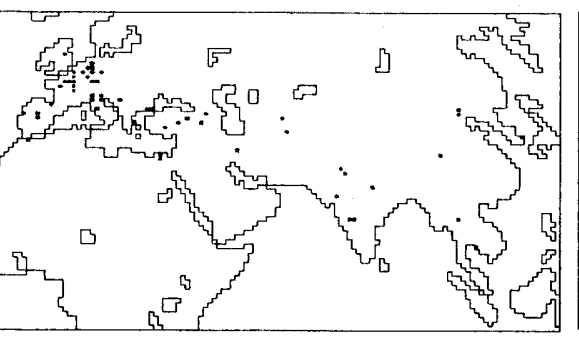

图-12「鈍尖形」の分布

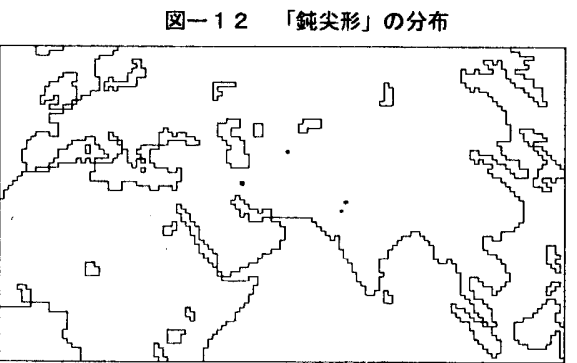

图-15 「䓯花形」の分布

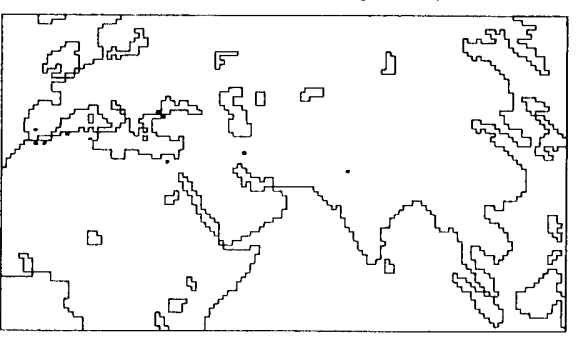

图-18「尖頭馬蹄形」の分布

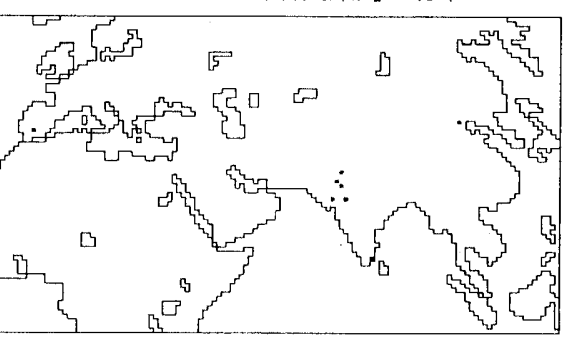

图-21「五莱形」の分布

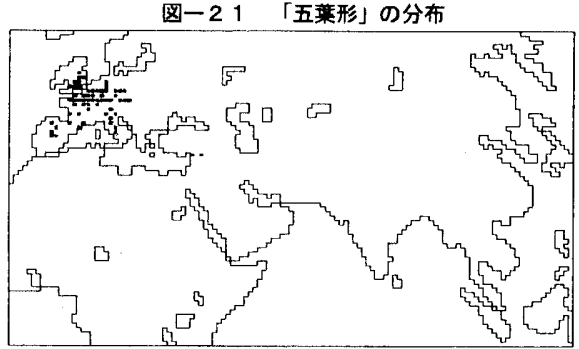

图-24 [束形]と[円柘形] の分布

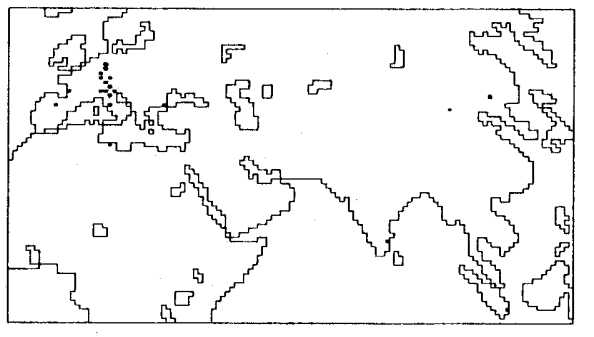

图一 10 「久円形」の分布

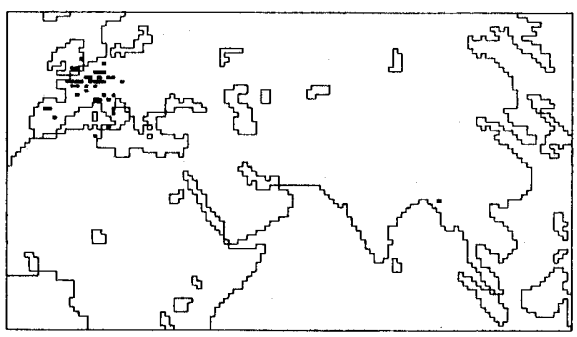

图一 13「等辺形」の分布

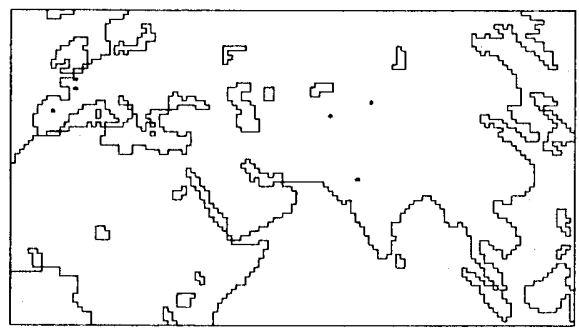

图-16「四心形」の分布

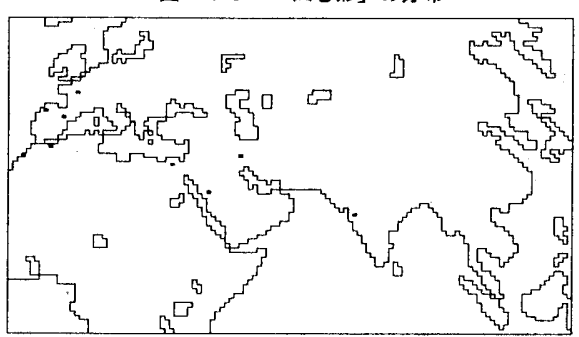

图一19「形馬蹄形」の分布

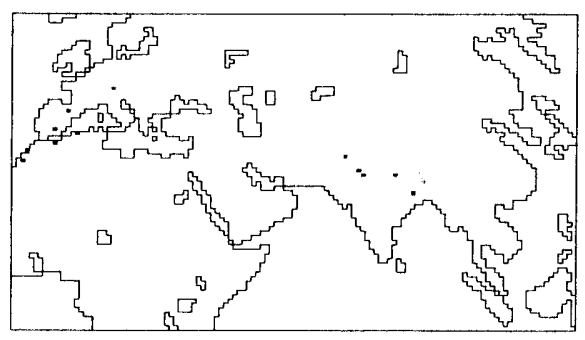

图一22「多菜形」の分布

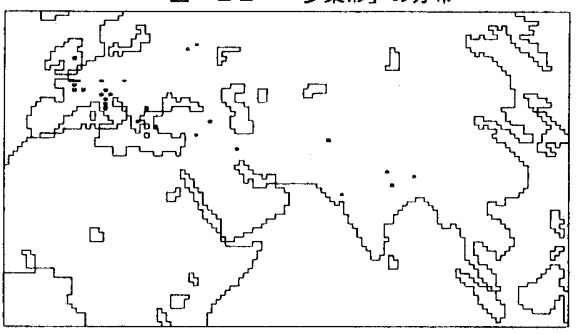

图-25 [非棈造] の分布 
形」,「半円形」の順に続く。一方で,「葱花形」,「三葉形」では【要 石】は用いられない。また，その他の【正面の形状】において，[尖 頭類], [変形尖頭類], 「尖頭馬蹄形」において【要石】が[無]の割合 が高い。【要石】の使用は, 特定の【正面の形状】と関連性が高いこ とが伺える(図-7)。

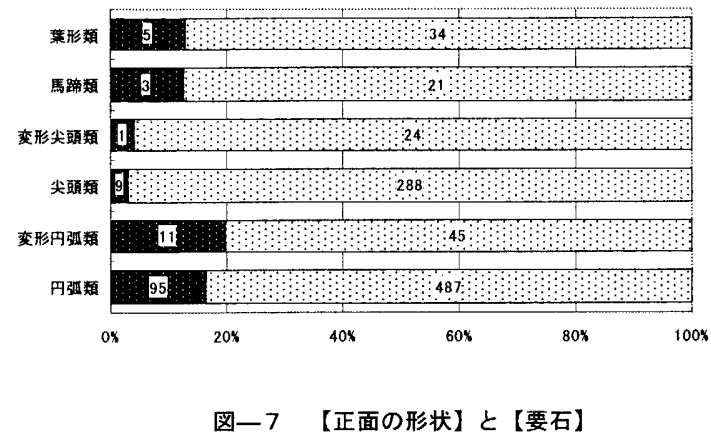

\section{5. アーチ横架材の分布}

分析対象の所在地に従って，正積図法であるグード=ホモロサイン 図法 ${ }^{8)}$ を用いて作成した地図にプロットし，【正面の形状】の各類型 の分布を中心に考察する。

全体のデータの分布をみると，サンプルがヨーロッパに集中し，中 近東，インド，中国東部に平均に分布する。アフリカ北部，ロシア， 中央アジア，モンゴル，東南アジアも散見される。ヨーロッパでは, フランス, ドイツ, イタリア北部, イギリス南部が分布の中心地とし て，全データの半分を占める(図一8)。

(1) [円弧類]

(1)「半円形

もっともシンプルな形状で，他の形状に比べ，より広い範囲に分布 している。大きくヨーロッパ, 中近東, インド, 中国の四つの地域に 分けることができる。ヨーロッパを詳しく分析すると, 主にフランス, イタリア，ドイツを中心に西ヨーロッパに集中しており，ほかの地域 にも拡散している。中国では，東部に集中し，東南部まで広がってい る。インドにも広い範囲に分布している(図一-9)。

(2)「久円形」

「半円形」の部分形態であり，サンプル数が少ないながらも広い範 囲に分布している。地域分布は, 西ヨーロッパに偏っており, イタリ ア，ドイツを中心にスペイン，フランスにも見られる。その他の地域 ではロシア，中国北部，インド，トルコ，東南アジア，北アフリカで 散見される（図一10）。

(2) [変形円弧類]

「心形」は西ヨーロッパを中心に，中近東，インドで局地的分布を 見せる。西ヨーロッパでは，イタリア北部，ドイッ，フランス，スペ インにほぼ均等に分布している（図－11）。

(3) [尖頭類]

(1)「鈚尖形」

広く東西に展開し、ューラシア全土に分布している。北アフリカ, 中東，インド，中国，韓国，インドでも，数は少ないながらも，広範 囲に分布している（図一－12）。

(2)「等辺形」と〔鋭尖形」

ヨーロッパの代表的なアーチ形態といえ, 西ヨーロッパに集中分布 し，中央アジアや中国にも見られる。西ヨーロッパでの分布を詳しく
見ると,フランス, ドイツに重点的に分布し，その他イギリス，スペ イン,イタリアにほぼ均等に分布している（図-13，図-14）。

(4) [変形尖頭類]

(1)「苟花形」

中近東地域とインドに局地的分布を見せる（図-15）。

(2)「四心形」

分布地域は大きくヨーロッパと中央アジアに分けられる。ヨーロッ パでは全地域的な分布ではなく，フランス，スペインに分布が偏る。 中央アジアでは「葱花形」の変化と見られ，ヨーロッパは「等辺形」 の変化であることが推測される（図－16）。

(3)「直線二心形」

中近東を中心としてヨーロッパ，北アフリカ，インドまで分布する (図- 17 )。

(5) [馬蹄類 $]$

(1)「尖頭馬蹄形

北アフリカを中心としながらも，スペイン，中近東，中央アジアま で拡散している（図一18）。

(2)「円形馬蹄形」

ヨーロッパ, 北アフリカ, 中近東とインド地域に局地的に分布して いる。ヨーロッパでは, フランス, スペインに分布し, 他の地域への 拡散は見られない(図一19)。

(6) [葉形類]

(1)「三葉形」

ヨーロッパと中央アジア，インドに主に分布し，中近東には見られ ない。また, ヨーロッパではイギリス, フランス, スペインとイタリ ア北部に散見できる。北ヨーロッパまでは分布していない(図ー20)。 (2)「五葉形」

インドを中心としつつ，中国，スペインで局地的に分布しており， 他の地域ではほとんど見られない（図－21）。

(3)「多葉形」

ヨーロッパ，北アフリカと中央アジアに分かれて分布し，他の地域 一の拡散は見られなかった（図一22）。

他の属性の分布から，【スパンの大小】の［巨大］（図-23）、【断 面の形状】の [円弧形 $]$ と [束形] (図-24) はヨーロッパ以外の 地域にはほとんど見られず，フランス，ドイツ，イタリア北部を中心 に拡がる。

\section{6. まとめ}

本研究では，ユーラシア圈におけるアーチ横架材をその形態から分 類し，属性間の関係と分布について考察した。

（1）【正面の形状】の各類型の特徴は，その分布を中心に次のよう にまとめられる(図一2 6 )。

(1) [円弧類]江各属性に平均した分布を見せ，アーチ横架材の基本形 としてユーラシア圈のほぼ全域に分布しており，構法様式の伝播とい うより，技術的に自発生成する一般的なものと推測される。

(2) [変形円弧類] (「三心形 1 ) は, 「半円形」の変化形として, 要石の 意味を強調するものである。[変形円弧類]はヨーロッパを中心とし， アジアの各地にも散見でき，それは，植民地化による伝播があったた めであると推測できる。

(3) [尖頭類] は, 垂直性を強調するため, 断面の束型を重ね合わせ, 
また，壁面を凹ませて重厚な表現とし尖頭の薄弱感を弱めている。[尖 頭類］はゴシック様式の代表的ア一チ横架材であり，[円弧類］とと もにア一千横架材の基本形である。「鈍尖形」は形状的に「半円形」 と似ており, 分布も類似し、ユーラシア圈に広く分布している。「等 辺形」と「鋭尖形」はゴシック様式として，ヨーロッパに集中する傾 向が強く，宗教による東・東南アジアへの伝播も推測される。

(4) [変形尖頭類] は, 立面形状の変化を求め, かつ壁面から突出して 自身の形状を強調することから立面の装飾性と記号性を重視する傾 向が見える。

(5) [馬蹄類］は断面形状がシンプルで，壁面の一部とも見えることか ら, 自身の形状を強調するより, ア一チ下の馬蹄形空間の輪郭を強調 する傾向がある。

（6） [葉形類］は小さいアーチを多用し，壁面から突出して，建築物の 構造体から分離寸る傾向が強い。[葉形類]はインドを中心としたブロ ックと西ヨーロッパ，北アフリカが中心のブロックにわかれて分布し， 中国北部，インド，ロシアにも散見できる。

[変形尖頭類], [馬蹄類], [葉形類]はイスラム宗教地域に集中して いる。イスラム様式地域に分布するア一チは【正面の形状】に多様性 が見られる。

（2）各地域のア一チ横架材の特徴は，次のようにまとまられる。 西ヨーロッパには，ほぼすべてのアーチ横架材様式が存在し，しか も「巨大」なものが多く、ア一チ技術の発達がうかがえる。東ヨーロ ッパでは西ヨーロッパとは異なる分布をみせる。「半円形」と「鈍尖 形」はみられるが，「鋭尖形」と「等辺形」はごく少ない。比較的単 純な構成はビザンツ文明の影響が強い。北ヨーロッパとロシアではは っきりした分布傾向がみられない。中近東地域も多種類のアーチ横架
材が確認できる。インド地域では，他地域に比べ，[変形尖頭類]と [葉 形類]，特に「五葉形」の存在が著しい。東アジアでは研究対象も少 なく,アーチ横架材の種類も他地域に比心゙少ない。そのなか，[円弧 類]がもっとも多く，[尖頭類]と [葉形類]はごくわずかである。巨大 アーチは一つも得られなかった。中央アジアにおける[尖頭類]の存在 は，西からの伝播と見られる。[葉形類]と[変形円弧類]の存在は，イ ンドからの影響と推測される。アフリカの北西部とスペインの南部で は[馬蹄類]の分布が顕著である。東南アジア地域では，[円弧類]，[尖 頭類]，[変形円弧類], [葉形類]の存在が見られる。[葉形類]はイン ド地域からの影響と推測される。

（3）図-2 6 では，グレーが濃くなることによって，多く種類のア 一チ横架材がその地域に共存することを表す。スペインとフランスの 北西部，地中海の東岸地域，インドの西部，中国の北東部では複数類 型のア一千横架材の共存が確認でき，文化様式の混交が感じられる。

参考文献に示した一連の研究を参照すると, 歴史的建築においても, その材料は風土から影響を受けていることが分かる。しかし一般住居 建筑の構法に比べれば，歷史的建築の構法の分布は風土よりも文化・ 文明の伝播による部分が大きい。アーチ横架材と水平横架材の時代変 遷の考察を踏まえたうえで, 構法様式の伝播のありかたを考察するこ とを今後の研究課題としたい。

注

1）この概念については参考文献の 5)～8)を参照。

2) 参考文献 9)。

3）伝播とは，単純には「次々に伝わって広まること」，文化人類学では「二 つの集団ないし文化を接触したとき，一方から他方へ文化要素が移るこ v と」とされるが，近年，ある技術や様式がその社会に成立するにはそれな

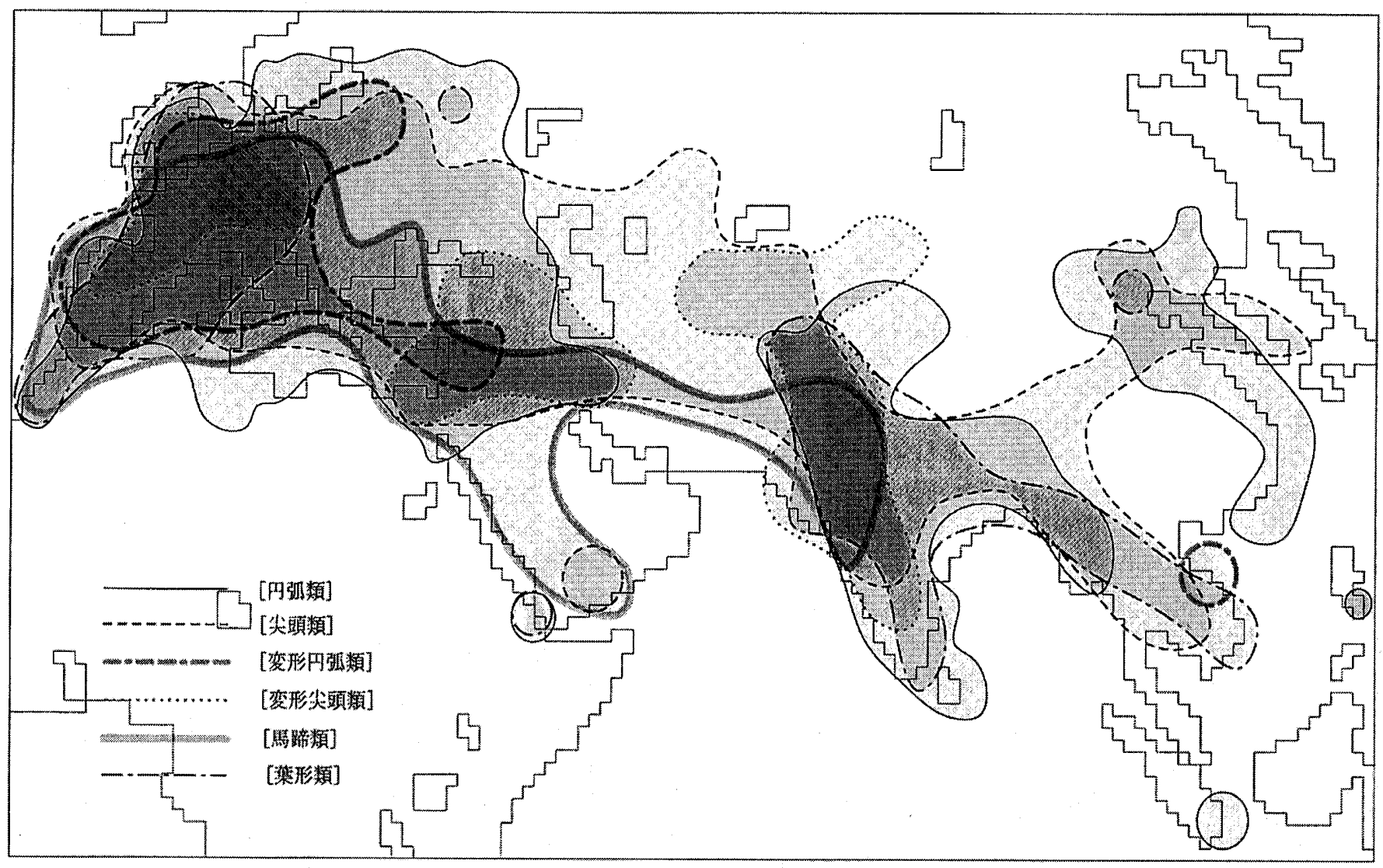

図-26【正面の形状】の各分類の分布図 
りの下地があったのであり，一方的に文明の伝播と解釈寸るのは偏見であ るという考え方が強くなっている。本論では，構法様式の特殊性と分布の 時代考察から，伝播と推測でき，特に必要な場合にこの用語をもちいる。

4）精吅で組織的な, 持続的建築様式であり, 社会的な用途としては宗教建 築や宮殿など，集合表象としての意味をもつ建築に多い。用途としては宗 教建築，あるいは宫殿建築である場合が多い。

5）資料抽出文献の 1) 51)。

6）歴史上確固たる文明（たとえば文字，鉄器，車輪などを有する文明）が 発達し，それが今日まで続いている地域は，ューラシアの東西に長い帯状 の地域のみである

7） 19 世紀後半に始まった近代化現象は, 構法を大きく変えた。構法的に は主に鉄の大量使用によるもので,こういった近代的建築はサンプルから 除く。

8）赤道上の経度 1 度の距離を基準とした正四角形グリッド（1グリッド= 約 1.24 万 $\mathrm{km}^{2}$ ) で分割する。その結果, 対象圈域は東西方向 125 , 南 北方向 70 に分割され, グリッド数 $8 ， 750$ 個となった。グリッドに沿 って簡略化した地図に各サンブルを所在地に従って入力した。

\section{抽出文献}

1) S.Lloyd, H.W.Muller, R. Martin: History of World Architecture; ANCIENT ARCHITECTURE, HARRY N. ABRAMS, INC.

2) J. B. Ward-Perkins : History of World Archi tecture; ROMAN ARCHITECTURE HARRY N. ABRAMS, INC.

3) C. A. Mango : History of World Archi tecture; BYZANTINE ARCHITECTURE, HARRY N. ABRAMS, INC.

4) J. D. Hoag : History of World Architecture; ISLAMIC ARCHITECTURE, HARRY N. ABRAMS, INC.

5) H. E. Kubach:History of World Archi tec ture; ROMANESQUE ARCHITECTURE, HARRY N. ABRAMS, INC

6) L.Grodecki : History of World Architecture ; GOTHIC ARCHITECTURE, HARRY N. ABRAMS, INC.

7) P. Murray: History of World Archi tec ture ; RENAISSANCE ARCHITECTURE, HARRY N. ABRAMS, INC.

8) C. Norberg-Schulz: History of World Architectu ; BAROQUE ARCHITECTURE, HARRY N. ABRAMS, INC.

9) C. Norberg-Schulz: History of World Architectu ; LATE BAROQUE AND ROCOCO ARCHITECTURE, HARRY N. ABRAMS, INC.

10) R. Middleton History of World Architecture ; NEOCLASSICAL AND 19TH CENTURY ARCHITECTURE, HARRY N. ABRAMS, INC.

11) M. Bussagli : History of World Archi tecture ; ORIENTAL ARCHITECTURE, HARRY N. ABRAMS, INC.

12) E. Guidoni: History of World Archi tecture ; PRIMITIVE ARCHITECTURE, HARRY N. ABRAMS, INC.

13）堀内清治, 增田義郎：世界の建策 1 古代オリエント・古代アメリカ, 学 習研究社

14）堀内清治:世界の建築 2 ギリシャ・ローマ, 学習研究社

15) 石井 昭: 世界の建築 3 イスラム, 学習研究社

16）柳 宗玄：世界の建築 4 口マネスク・東方キリス卜教，学習研究社

17）飯田 喜四郎：世界の建築 5 ゴシック, 学習研究社

18）鈴木博之:世界の建築 6 ルネサンス・マニェリスム，学習研究社

19）山田智三郎，世界の建築 7 バロック・ロココ，学習研究社

20）エンンリーコ・グイドー二: 図説世界建築史 1 原始建築, 本の友社

21）八ンス・ヴオルフガング・ミューラー，ミートン・ロイド : 図説世界建 築史 2 エジプト・メソポミア建筑，本の友社

22）ロラン・マルタン：図説世界建築史 3 ギリシア建築, 本の友社

23）J.B. ウォード・パーキンス:図説世界建築史 4 口ーマ建築, 本の友社

24）シリル・マンゴー：図説世界建築史 5 ビザンティン建筑，本の友社

25）ジョン・D・ホーグ：図説世界建築史 6 イスラム建築，本の友社

26）ハンス・エリッヒ・クーバッ八：図説世界建築史 7 ロマネスク建築, 本の友社

27）ルイ・グロデッキ：図説世界建築 8 ゴシック建築，本の友社

28）ピーター・マレー：図説世界建築10 ルネセンス建築, 本の友社

29）クリスティアン・ノルベルク：図説世界建築１１バロック建築，本の 友社

30）クリスティアン・ノルベルク : 図説世界建築 12 後期バロック・ロコ 二建築, 本の友社

31）・ロビン・ミドルトン，デイヴィッド・ワトキン：図説世界建築 13 新 古典主義・19世紀建筑 $(1)$, 本の友社

32）ロビン・ミドルトン, デイヴィッド・ワトキン: 図説世界建築 14 新 古典主義・19世紀建築 $(2)$, 本の友社
33）ユネスコ世界遺産センター監修：ュネスコ世界遺産（3：西アジア）講 啖社

34）ユネスコ世界遺産センタ一監修：ユネスコ世界遺産（4：東アジア・ロ シア）講談社

35）エネスコ世界遗産センター監修：エネスコ世界遺産（5：インド覀大 陸) 講談社

36) ユネスコ世界遺産センター監修：ユネスコ世界遺産 (6：東南アジア・才 セアニア）講談社

37）ユネスコ世界遺産センター監修：ユネスコ世界遺産（7：北・中央ヨー ロッパ）講談社

38）ユネスコ世界遺産センター監修：エネスコ世界遺産（8：西ヨーロッ パ) 講談社

39）ユネスコ世界遺産センター監修：コネスコ世界遺産（9：東南ヨーロッ パ) 講談社

40）ユネスコ世界遺産センタ一監修：エネスコ世界遺産(10：南ヨーロッ パ）講談社

41）ユネスコ世界遺産センター監修：エネスコ世界遺産(11：北・西アフリ 力) 講談社

42）神谷武夫:インドの建築，東方出版

43）太田邦夫：ヨーロッパの木造住宅, 駸々堂

44） N. ツルテム:モンゴル曼陀羅 3 寺院建築，新人物往来社

45）中国建築科学研究院:中国の建築, 小学館

46）光復書局企業股分有限公司: 中国古建築之美 1-10，中国建築工業出版 社

47）金元龍 他:韓国文化財大観 1 国宝 1，韓国文化財保護協会

48）金元龍 他:韓国文化財大観 3 宝物 1 ，韓国文化財保護協会

49) S. siribhad, E. H. Moore, M. Freeman: PALACES OF THE GODS, 講談社

50）大林太良:世界の大遺跡 12 アンコールとボロブドゥール, River Books

51）日本建築学会：日本建築図集，彰国社

\section{参考文献}

1）太田邦夫：東ヨーロッパの木造建築一架構方式の比較研究，相模書房， 1988

2）太田邦夫：住居における木造架構の比較研究（1-4)，新住宅普及会住 宅建築研究所報, 1977-1978, 1982-1983

3）布野修司，脇田祥尚，牧紀男，青井哲人:デサ・バヤンイインドネシア ロンボク島)における住居集落の空間構成, 日本建築学会計画系論文集, 第 478 号, pp. 61-68, 1995.12

4) 關銘宗(京都大学)，布野修司，田中禎彦(文化庁) : 台北市の寺廟 神壇の 類型とその分布に関する考察，日本建築学会計画系論文集，第 526 号，p p. $185-1.92,1999.12$

5）若山滋:構法の成立条件に関する研究 その 1 構法の分類と分布，日本建 築学会論文報告集, 第 317 号, pp. 69-74, 1982.7

6) 若山滋:構法の成立条件に関する研究 その 2 風土と構法，日本建築学会 論文報告集，第 323 号, pp. 94-98, 1983.1

7）若山滋: 構法の成立条件に関する研究 その3 構法環境条件としての気候, 日本建築学会計画系論文報告集, 第 347 号, pp. 34-39, 1985.1

8）若山滋 : 建築構法の存在様態に関する一般的属性，日本建築学全論文報 告集, 第 357 号, pp. 32-39, 1985. 11

9）若山滋，李強，宮地幸子，北川啓介，夏目欣昇：ユーラシア圈に扔ける 水平横架材の構法の分類と分布, 日本建築学会計画系論文集, 第 580 号, pp. $49-55,2004,6$

10）平田恭輔, 若山滋, 茶谷正洋:住宅の構法と形態に関する研究 その 6 構 法建築原理の分析，日本建築学会学術構演梗概集 (計画系)，pp. 805-806, 1978.9

11）若山滋:住宅構法と形態に関する研究 その8構法分類についての考察一 2，日本建築学会大会学術講演梗概集（計画系)，pp.957-958，1979.9

12）若山滋：風土に生きる建築，鹿島出版会，1983.6 